In cooperation with the Wyoming Department of Agriculture (WDA) and the Wyoming Department of Environmental Quality (WDEO)

\title{
Pesticides in Ground Water - Park County, Wyoming, 1997
}

In 1991, members of local, State, and Federal governments, as well as industry and interest groups, formed the Ground-water and Pesticide Strategy Committee to prepare the State of Wyoming's generic Management Plan for Pesticides in Ground Water (SMP). Part of this management plan is to sample and analyze Wyoming's ground water for pesticides. In 1995, the U.S. Geological Survey, in cooperation with the Ground-water and Pesticide Strategy Committee, began implementation of the SMP by Sampling wells in Goshen County, Wyoming. In 1997, baseline monitoring began in Park County.

\section{PESTICIDES IN GROUND WATER}

Synthetic organic pesticides are used to control weeds, insects, and other organisms in a wide variety of agricultural and nonagricultural settings. The use of pesticides has helped to make the United States the largest producer of food in the world and has provided other benefits, but the use has also been accompanied by concerns about

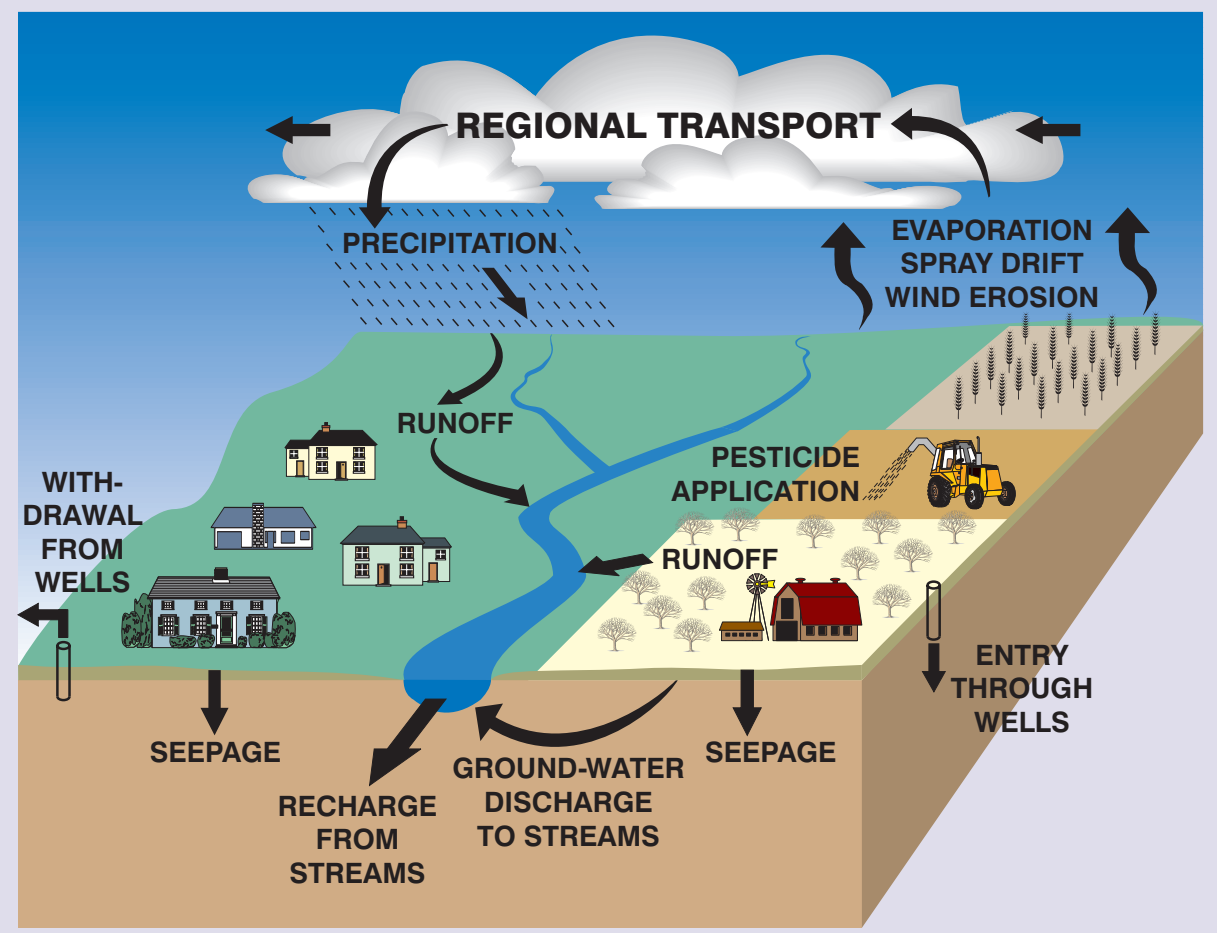

Figure 1. Pathways of pesticide movement in the hydrologic cycle (modified from U.S. Geological Survey Fact Sheet FS-244-95). their potential adverse effects on the environment and human health. A potential pathway for the transport of pesticides is through hydrologic systems, which supply water for both humans and natural ecosystems. Water is one of the primary ways pesticides are transported from an application area to other locations in the environment (fig. 1).
Pesticide contamination of ground water is a national issue because ground water is used for drinking water by about 50 percent of the Nation's population. Concern about pesticides in ground water is especially acute in rural agricultural areas where over 95 percent of the population relies upon ground water for drinking water.

\section{WYOMING'S PESTICIDE MANAGEMENT PLAN}

In 1991, the Ground-water and Pesticide Strategy Committee (GPSC) began developing the generic State Management Plan for Pesticides in Ground Water for the State of Wyoming. The SMP will be required by the U.S. Environmental Protection Agency (EPA) in order for individuals to continue using certain pesticides in Wyoming. The SMP includes information relating to agencies and individuals involved with the implementation of the SMP, ground-water monitoring, methods of preventing ground-water contamination, and what the responses will be to detections of pesticides in ground water. 
Table 1. Baseline monitoring for pesticides in Park County, 1997-98.

$[\mu \mathrm{g} / \mathrm{L}$, micrograms per liter; $\mathrm{E}$, estimated; trace, pesticide detected, but at a concentration too small to quantify]

\begin{tabular}{|c|c|c|c|c|c|c|}
\hline Pesticide & $\begin{array}{l}\text { Pesticide action } \\
\text { (Farm Chemicals } \\
\text { Handbook and } \\
\text { Dictionary, 1996) }\end{array}$ & $\begin{array}{l}\text { Number } \\
\text { detected/ } \\
\text { Number } \\
\text { sampled }\end{array}$ & $\begin{array}{l}\text { Minimum } \\
\text { reporting } \\
\text { limit } \\
(\mu \mathrm{g} / \mathrm{L})\end{array}$ & $\begin{array}{c}\text { Maximum } \\
\text { concentration } \\
(\mu \mathrm{g} / \mathrm{L})\end{array}$ & $\begin{array}{c}\text { Average } \\
\text { concentration } \\
\text { of detections } \\
(\mu \mathrm{g} / \mathrm{L})\end{array}$ & $\begin{array}{c}\text { Safe drinking } \\
\text { water standard } \\
(\mu \mathbf{g} / \mathbf{L})\end{array}$ \\
\hline \multicolumn{7}{|c|}{ Focal pesticides detected in Park County ground water } \\
\hline Aldicarb Sulfone ${ }^{2}$ & Insecticide, nematicide ${ }^{3}$ & $8 / 54$ & 0.016 & 0.36 & 0.2 & $35^{4}$ \\
\hline Aldicarb Sulfoxide $^{2}$ & Insecticide, nematicide ${ }^{3}$ & $8 / 54$ & 0.021 & $2.5 \mathrm{E}$ & 0.5 & $35^{4}$ \\
\hline Atrazine & Selective herbicide & $42 / 54$ & 0.001 & 0.18 & 0.02 & 3 \\
\hline Hexazinone & Selective herbicide & $7 / 54$ & 0.05 & 0.062 & 0.009 & $200^{5}$ \\
\hline Metolachlor & Selective herbicide & $1 / 54$ & 0.05 & trace & trace & $70^{5}$ \\
\hline Picloram & Systemic herbicide & $1 / 54$ & 0.05 & 0.46 & $0.46 \mathrm{E}$ & 500 \\
\hline Simazine & Selective herbicide & $6 / 54$ & 0.05 & trace & trace & 4 \\
\hline Tebuthiuron & Herbicide & $3 / 54$ & 0.01 & 0.24 & 0.16 & $500^{5}$ \\
\hline \multicolumn{7}{|c|}{ Non-focal pesticides detected in Park County ground water } \\
\hline Prometon & Non-selective herbicide & $18 / 54$ & 0.05 & 0.49 & 0.08 & $100^{5}$ \\
\hline \multicolumn{7}{|c|}{ Focal pesticides not detected in Park County ground water } \\
\hline Alachlor & Aldicarb & Bromacil & Clopyralid & Cyanazine & 2,4-D & DCPA \\
\hline Dicamba & Difenzoquat $^{6}$ & Metsulfuron $^{6}$ & Metribuzin & Telone & & \\
\hline
\end{tabular}

1EPA Maximum Contaminant Level unless otherwise noted (EPA, 1996).

${ }^{2}$ Degradation product of Aldicarb.

${ }^{3}$ Action of parent product, Aldicarb.
${ }^{4}$ EPA Drinking Water Equivalent Level (EPA, 1996).

${ }^{5}$ EPA Lifetime Health Advisory Level (EPA, 1996).

${ }^{6}$ No method of analysis available.
One critical part of the SMP is ground-water monitoring. The ground-water sampling program has two phases. The first phase involves baseline monitoring, which is an initial survey of the pesticides detected in a county's ground water. The second phase is problem identification monitoring, which is used to gather more information about the ground water near wells with significant pesticide detections.

Baseline monitoring is directed by a county rank and the vulnerability of the ground water to pesticides. During the development of the SMP, the GPSC evaluated each county in Wyoming to determine the potential vulnerability of the county's ground water to pesticides. Each county was ranked based on the extent of cropland and urban areas in the county, as well as the amount of pesticides sold within the county in 1991.

A ground-water vulnerability map is prepared for the uppermost or shallowest aquifer. The map, a summation of seven maps describing the hydrogeology and land use, is used to assist in the selection of monitoring sites in each county. The monitoring focuses on areas where the ground water is most vulnerable.

The GPSC selected 18 pesticides of focus and 2 degradation products to be sampled as part of the SMP (table 1). An additional 66 pesticides and degradation products are included in USGS pesticide analyses, leading to possible detections of non-focal pesticides. Ground water from all wells in the baseline monitoring program was analyzed for the pesticides listed in table 1 , with the exception of Difenzoquat and Metsulfuron. 


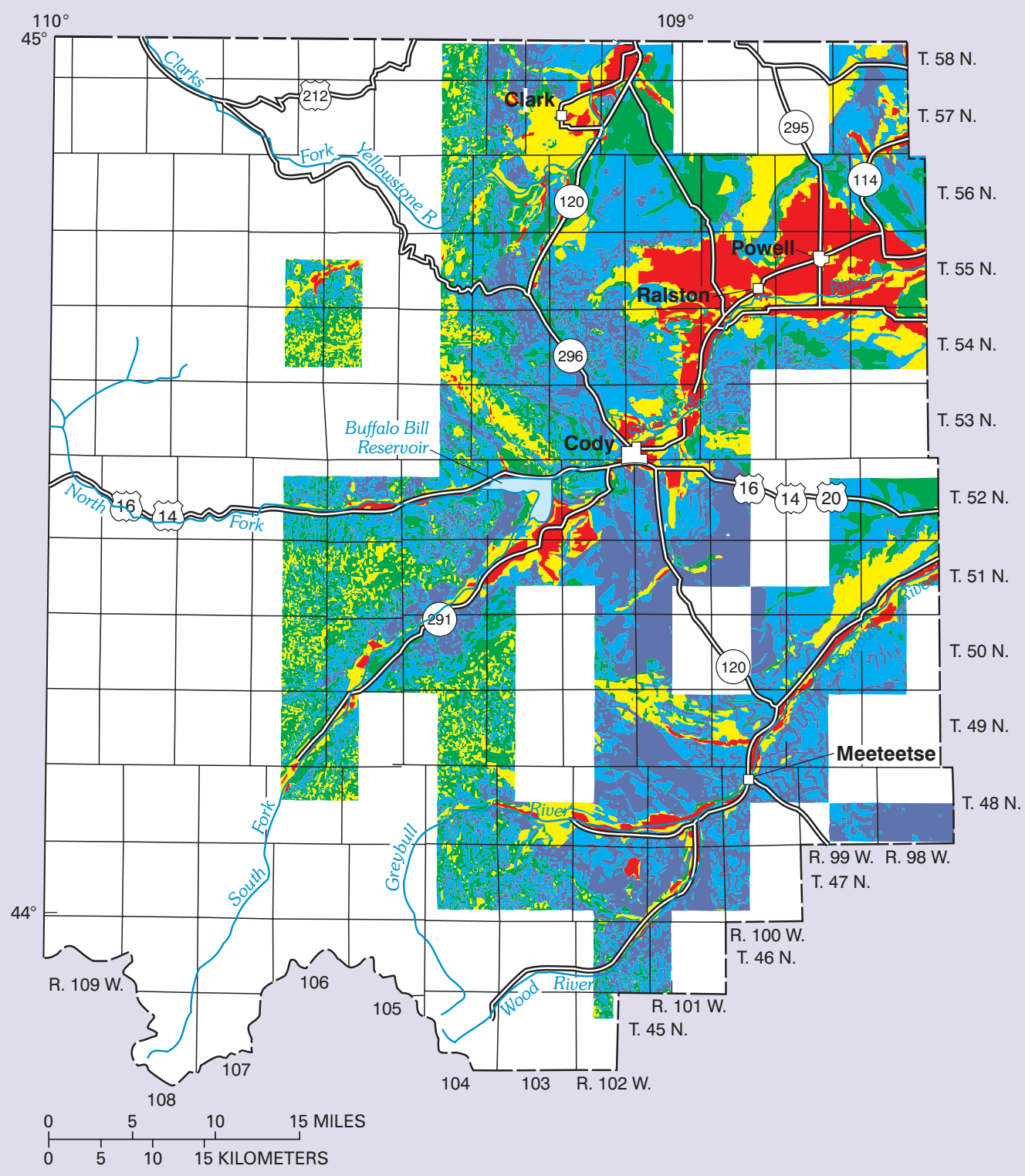

EXPLANATION

VULNERABILITY TO

PESTICIDE

CONTAMINATION

High

$\square$ Medium high

Medium

Medium low

Low

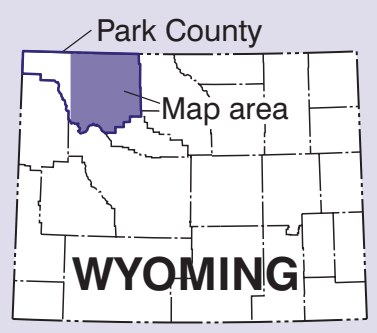

Figure 2. Vulnerability of Park County ground water to pesticide contamination (University of Wyoming Spatial Data and Visualization Center, written commun., 1998).

The ground-water sampling part of the SMP began in Goshen County in 1995. The goal of the sampling program is to collect ground-water samples for pesticide analyses in all 23 Wyoming counties.

\section{GROUND-WATER MONITORING IN PARK COUNTY}

The vulnerability of ground water in Park County was ranked second in Wyoming and sampling began in April 1997. The vulnerability map for Park County (fig. 2) was created by the University of Wyoming Spatial Data and Visualization Center. The alluvial and terrace aquifers, usually located in stream valleys and on benches, were identified as the most vulnerable to pesticides in Park County.

Twenty-seven sites were selected for baseline monitoring in Park County. All wells were selected in the two most vulnerable rankings (areas in red and yellow). The wells were inspected and selected with the assistance of the three Park County Conservation Districts. All sites were sampled twice, either during the spring and late summer of 1997, or the late summer of 1997 and spring of 1998. These time periods were selected to correspond with deepest and shallowest water-table conditions.

Six of the 18 pesticides of focus and the two degradation products were detected in Park County (table 1). All levels of pesticides detected were less than two-thirds of the drinking water standard or its equivalent established by the EPA for domestic supplies (U.S. Environmental Protection Agency, 1996). Although these standards do not apply to private domestic wells, they do provide a reference to the acceptable amount of chemicals in drinking water. 


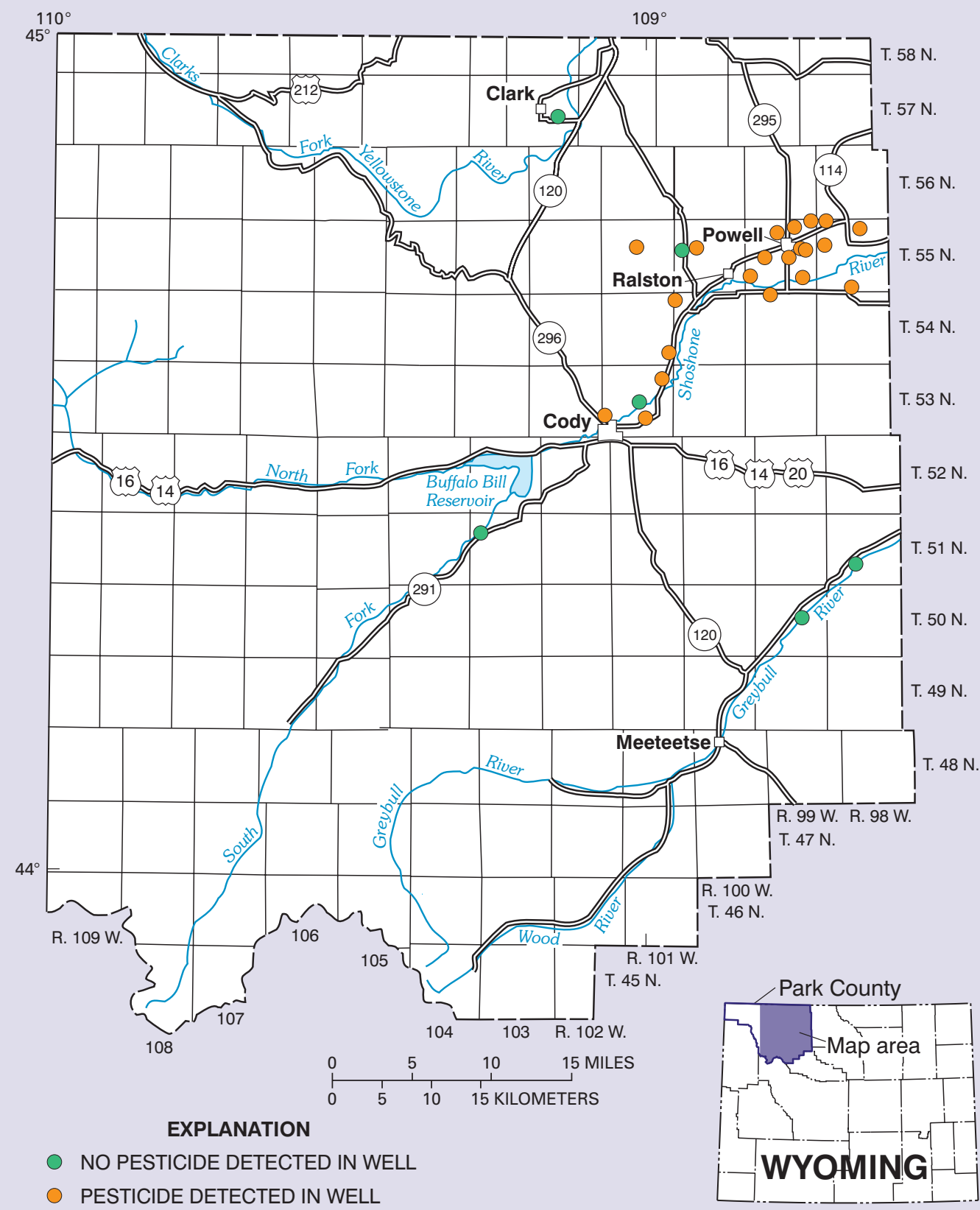

Figure 3. Location of wells sampled in Park County, and notation of pesticide detection in each well.

At least one pesticide was detected in 21 of the 27 wells sampled in the county (fig. 3 ). The pesticide with the highest concentration was Aldicarb sulfoxide, a degradation product of Aldicarb. More than 75 percent of the detections were trace quantities. A trace quantity indicates the pesticide was detected, but at a level too small to quantify. Atrazine was the most commonly detected pesticide, detected in 42 samples from 21 of the 27 wells. given to local Conservation Districts interested in pesticides in ground water in Park County. The information can be used by citizens and local governments to help understand current conditions.

Baseline sampling in Washakie County was also started in 1997. Fremont, Lincoln, and Laramie County sampling will begin in August 1998. Results of all analyses are available from the U.S. Geological Survey in Cheyenne (Mason and Green, 1998).

\section{REFERENCES:}

Farm Chemicals Handbook and Dictionary, 1996: Willoughby, Ohio, Meister Publishing Co., variable pagination.

Mason, J.P., and Green, S.L., 1998, Water resources data, Wyoming, water year 1997: U.S. Geological Survey Water-data Report WY-97-2, $147 \mathrm{p}$.

U.S. Environmental Protection Agency, 1996, Drinking Water Regulations and Health Advisories: EPA 822-B-96-002.

U.S. Geological Survey, 1995, Pesticides in ground water: U.S. Geological Survey Fact Sheet FS-244-95, 4 p.

\section{FOR MORE INFORMATION, CONTACT:}

Jim Bigelow

Wyoming Department of Agriculture 2219 Carey Avenue

Cheyenne, Wyoming 82002

(307) $777-7324$

Kevin Frederick

Wyoming Department of

Environmental Quality,

Water Quality Division

4th Floor, Herschler Building

Cheyenne, Wyoming 82002

(307) 777-7781

District Chief

U.S. Geological Survey, WRD

2617 E. Lincolnway, Suite B

Cheyenne, Wyoming 82001

(307) 778-2931

Email:

staterep_wy@mailcheyenne.cr.usgs.gov Internet:

http://wyoming.usgs.gov/welcome.html

This document was prepared by the U.S. Geological Survey (USGS), the Wyoming Department of Agriculture (WDA), and the Wyoming Department of Environmental Quality, Water Quality Division (WDEQ). All agencies are members of the Groundwater and Pesticide Strategy Committee.

The use of trade, product, industry, or firm names is for descriptive purposes only and does not imply endorsement by the U.S. Government.

-Prepared by Cheryl A. Eddy-Miller

- Layout and final illustrations by Suzanne C. Roberts 